DOI: $10.19195 / 2082-8322.9 .4$

Mateusz Komander

ORCID: 0000-0003-2194-7837

Uniwersytet Wrocławski

\title{
Randki w sieci, czyli flirt w objęciach konsumpcjonizmu
}

Sposoby nabywania rozmaitych dóbr i usług od dawna cieszą się sporym zainteresowaniem ekspertów. W końcu to, jak konsumenci pozyskują dane dobra i przede wszystkim, dlaczego to robią, stanowi punkt odniesienia dla wielu marketingowych przedsięwzięć. Na polu nauki napotkać można wiele analiz odnoszących się do konsumowanych produktów bądź zamawianych usług. Zazwyczaj jednak konsumpcjonizm kojarzony jest ze wzmożonym nabywaniem rozmaitych dóbr.

Konsumenci mogą w szybki i komfortowy sposób gromadzić niezliczoną ilość produktów poprzez zakupy w sklepach stacjonarnych czy internetowych. Producenci za wszelką ceną starają się w jak najszybszym czasie dotrzeć do potencjalnych klientów. W końcu za wszystkim idzie to, czego przedsiębiorcy oczekują najbardziej — zysk. Co jednak jeśli pożądanymi dobrami stają się uczucia? Czy konsumpcjonizm ma wpływ na jakość i sposób zawierania relacji online? Czy w dobie nowych technologii stajemy w obliczu diametralnych przemian najintymniejszej sfery naszego życia?

Już na wstępie należy zwrócić uwagę na problem związany z próbą definicji terminu „konsumpcjonizm”. Otóż słowo „konsumować” (consume) to określenie wywodzące się z XIV wieku, a odnoszące się do procesu zużywania, roztrwaniania czy też niszczenia ${ }^{1}$. Zauważyć można zdecydowanie negatywne nacechowanie przytoczonego określenia. Również termin „konsumpcja” (consumption) nacechowany był pejoratywnie, gdyż odnosił się do wyniszczających chorób ${ }^{2}$. Według Szczepańskiego konsumpcja związana jest $\mathrm{z}$ bezpośrednim zaspokojeniem danych potrzeb przez zu-

1 R. Williams, Keywords: A Vocabulary of Culture and Society, New York 1976, s. 68.

2 A. Aldridge, Konsumpcja, przeł. M. Żakowski, Warszawa 2006, s. 10. 
życie odpowiednich środków. To także proces oparty na działaniach podjętych przez człowieka, by zaspokoić swoje potrzeby, oraz faza reprodukcji społecznej³.

Przytoczone powyżej płaszczyzny odnoszą się kolejno do wykorzystania dóbr przez konkretną jednostkę, zachowań konsumpcyjnych podejmowanych na rynku, a w końcu do spożycia danych dóbr w odniesieniu do kontekstu społecznego czy kulturowego ${ }^{4}$. Biorąc pod uwagę przytoczone stanowiska, zauważyć można, iż konsumpcja rozumiana jest zazwyczaj jako zużycie, zaspokojenie danych potrzeb lub też akt kupna. Najczęściej jednak wspomnianym terminem określa się proces zaspokajania własnych potrzeb ${ }^{5}$.

Nadmierne skupienie na zaspokajaniu własnych potrzeb, a także nieustanne nabywanie dóbr prowadzić może do wykształcenia się cech narcystycznych wśród członków danego społeczeństwa. Umacnianie tego typu postaw wiązać się może z tak zwaną kulturą narcyzmu. Duży wpływ na to mają środki masowej komunikacji. Istotne jest przede wszystkim to, by odbiorcy bezwiednie pochłaniali kolejne porcje serwowanych im informacji. To także marketing i reklama, na podstawie których konsumenci tworzą swoje pragnienia, przez co nieustannie czują się niespełnieni. Należy nadmienić, iż rozpad relacji rodzinnych również nie jest sprzyjającym zjawiskiem. Skutkuje to problemami w przekazywaniu kultury kolejnym pokoleniom, a także narcystycznym przywiązaniem do dóbr materialnych ${ }^{6}$. Wszystko to prowadzić może do patologicznych form konsumpcji, które oddalają nas od świata rzeczywistego ${ }^{7}$.

Konsumpcjonizm skutecznie przeniknął wiele płaszczyzn naszego życia. Marek Krajewski wprost podkreśla, że towarem tak naprawdę może zostać wszystko — od zjawisk patologicznych czy tragicznych aż po życie rodzinne oraz prywatność ${ }^{8}$. Dziedziny życia, które nie uciekają przed konsumpcjonizmem, mają szansę zaistnienia. Natomiast sfery życia, które unikają procesów komercjalizacji, wyrzucane są poza nawias społeczeństwa ${ }^{9}$. Co więcej, Zygmunt Bauman podkreślił, iż konsumenci również są konsumpcyjnymi towarami. Właśnie ta zależność umożliwia im bycie pełnoprawnymi członkami społeczeństwa ${ }^{10}$.

Proces utowarowienia człowieka niewątpliwie zauważyć można w przestrzeni serwisów randkowych. Użytkownicy Internetu tworzą tam swoje profile w celu poznania interesującej ich osoby. Prywatne ja zostaje uzewnętrznione i poddane ocenie ze stro-

3 J. Szczepański, Konsumpcja a rozwój człowieka, Warszawa 1981, s. 133-134.

4 Ł. Iwasiński, Socjologiczne dyskursy o konsumpcji, Gdańsk 2016, s. 42-43.

5 Ibidem, s. 42.

6 A. Aldridge, op. cit., s. 96.

7 Ibidem, s. 97.

8 M. Krajewski, Konsumpcja i współczesność. Opewnej perspektywie rozumienia świata społecznego, „Kultura i Społeczeństwo” 1997, nr 3, s. 15.

9 Ł. Iwasiński, op. cit., s. 110.

10 Z. Bauman, Konsumowanie życia, Kraków 2016, s. 66. 
ny abstrakcyjnej widowni ${ }^{11}$. Już sam proces tworzenia opisów własnej osoby sprzyja przeobrażeniu jej w obiekt. Odbywa się to głównie przy zastosowaniu elementów wizualnych oraz języka ${ }^{12}$. W końcu właściciele profilu tworzą swego rodzaju wizytówkę, która ma przedstawić ich osobę w jak najkorzystniejszym świetle. Wszystko po to, by zdobyć zainteresowanie pozostałych zwolenników wirtualnych randek. Dariusz Czaja zaznacza wprost, iż „ciało współczesne jest ciałem zwizualizowanym”13.

Użytkownicy serwisów randkowych sporą uwagę poświęcają wspomnianym aspektom cielesnym. Tworzą bogate i barwne opisy swoich ciał. Chris Shilling podkreśla niezwykłą istotność przedstawionego obrazu siebie. Mianowicie, jeżeli obraz ten będzie społecznie akceptowalny, to skutkować on będzie sukcesem zarówno ekonomicznym, jak i społecznym. Środki umożliwiające modyfikacje własnej tożsamości są ściśle powiązane $\mathrm{z}$ dobrami konsumpcyjnymi ${ }^{14}$. To kolejne stanowisko łączące cielesność z utowarowieniem znamiennym dla współczesnych państw Zachodu.

Skupiając się na zjawisku autoprezentacji, nie sposób nie wspomnieć o koncepcji życia jako teatru, którą zaproponował Erving Goffman. Otóż uczestnik społeczeństwa nieustannie ogrywa role, co prowadzić ma do uzyskania przez niego korzyści i zrealizowania niezbędnych potrzeb. Człowiek, niczym aktor, będąc na scenie, przybiera maskę i swego rodzaju pozę, by zaprezentować się we wcześniej ustalony sposób. Natomiast opuszczając wspomnianą scenę, może zachowywać się nieco swobodniej, a tym samym wyzbyć się maski. Podobnie jest z człowiekiem, który opuszcza daną przestrzeń społeczną, by udać się w miejsce prywatności ${ }^{15}$.

Goffman podkreśla istotną rolę autoprezentacji w procesie funkcjonowania człowieka w życiu społecznym. Ukazanie siebie samego w społecznie akceptowany sposób umożliwia zaspokojenie swych potrzeb. Należy mieć na uwadze fakt, iż sposoby prezentowania swojego ciała różnią się w zależności od rzeczywistości społecznej, w której funkcjonuje dana osoba. Bourdieu wprost zaznaczał niezwykły wpływ klasy społecznej na aspekty ludzkiej cielesności. Francuski socjolog proces ten określał mianem kapitału fizycznego. Mowa w tym wypadku o symbolicznych znaczeniach obecnych w ciele - władzy, pozycji społecznej itp. Ciało jest akumulacją znaczeń, które mogą zostać wymienione na kapitał ekonomiczny (na przykład pieniądze), kapitał kulturowy (między innymi wykształcenie) czy kapitał społeczny (jak sieci i relacje międzyludzkie). Oczywiście, by pomnażać wspomniany kapitał fizyczny, należy rozwijać swoje ciało w społecznie akceptowany i uznany za wartościowy sposób.

11 E. Illouz, Uczucia w dobie kapitalizmu, Warszawa 2010, s. 115.

12 Ibidem.

13 D. Czaja, Wstęp, [w:] Metamorfozy ciała. Świadectwa i interpretacje, red. D. Czaja, Warszawa 1999, s. 8.

14 C. Shilling, Socjologia ciała, przeł. M. Skowrońska, Warszawa 2010, s. 104.

15 Zob. E. Goffman, Człowiek w teatrze życia codziennego, Warszawa 2011. 
Bourdieu zakłada, iż ma to znaczenie wobec chęci zdobycia pożądanych dóbr i usług, co także jest nawiązaniem do konsumpcyjnego modelu życia ${ }^{16}$.

Wspomniana wcześniej prezentacja własnej osobowości z oczywistych względów opiera się na wyeksponowaniu pozytywnych cech danego człowieka. Rzecz jasna, to członkowie danej społeczności, na bazie procesu socjalizacji, określają, które z cech są społecznie pożądane i które z nich mieszczą się w definicji atrakcyjnej osobowości. Niemniej, żaden z uczestników wirtualnych randek nie chce zostać odebrany przez resztę obserwatorów jako jednostka negatywna czy wręcz nieatrakcyjna. Z oczywistych względów kłóciłoby się to $\mathrm{z}$ celem, $\mathrm{w}$ jakim został założony profil właśnie w serwisie o charakterze randkowym.

Swoboda ukazywania siebie samego na profilu randkowym prowadzić może wręcz do tworzenia mitów odnośnie do swojej osoby. Mowa o tak zwanej mitologizacji własnej osobowości, która przejawiać się może w przesadnej idealizacji aspektów własnego ciała czy też charakteru. W cyberprzestrzeni możemy z łatwością zaprezentować swój ulepszony wizerunek, który każdy z nas posiada w zanadrzu ${ }^{17}$. Odnosić się on może nie tylko do aspektów cielesnych, ale także do tych związanych z życiem codziennym danego użytkownika - wykonywaną pracą zawodową, wykształceniem czy statusem społecznym. W końcu cenimy sobie takie cechy, jak życzliwość, inteligencję, wysoki prestiż czy wrażliwość. Bogdan Wojciszke podkreśla, iż ocena człowieka jest tym wyższa, im bardziej pozytywnie prezentują się jego cechy ${ }^{18}$.

Ponadto osoby uchodzące za atrakcyjne fizycznie odbierane są jako bardziej miłe, interesujące, wrażliwe czy szczęśliwe ${ }^{19}$. Warto wspomnieć także o poczuciu humoru, które często określane jest jako niezwykle atrakcyjna cecha potencjalnego partnera. W wirtualnym świecie pierwsze wrażenie niezwykle łatwo zbudować na bazie poczucia humoru, gdyż w tym celu wystarczy jedynie zastosować tekst pisany ${ }^{20}$. Co więcej, słowa ubarwić można dodatkowymi elementami - emotikonami czy GIF-ami, które w szybki sposób dookreślają charakter wysyłanych komunikatów. Ten aspekt komunikacji internetowej jest niezwykle istotny, gdyż pomaga uniknąć rozmaitych zakłóceń komunikacyjnych bądź mylnego odbioru danych treści.

Choć Internet pozwala nam na swobodną ekspresję swoich emocji, uczuć czy myśli, zauważyć można, że „wizytówki” tworzone przez internautów przybierają niezwykle ujednolicony charakter. Spowodowane jest to istotną rolą języka w tego typu przestrzeniach, który składa się ze ściśle określonej liczby słów. Użytkownicy korzystają z określeń odpowiadających kulturowym scenariuszom atrakcyjnych osobowości. Autoprezentacja oparta jedynie na słowach prowadzi do monotonii i urzeczowienia

16 C. Shilling, op. cit., s. 139-140.

17 Zob. A. Aboujaoude, Wirtualna osobowość naszych czasów. Mroczna strona e-osobowości, Kraków 2012.

18 B. Wojciszke, Człowiek wśród ludzi. Zarys psychologii społecznej, Warszawa 2002, s. 283.

19 Ibidem, s. 286-287.

20 P. Wallace, Psychologia Internetu, Poznań 2001, s. 196. 
wspomnianych opisów. Jest to paradoks sieci $-\mathrm{z}$ jednej strony użytkownicy portali randkowych dążą do wyjątkowości, a z drugiej spotykają się z monotonią i ujednoliconym przekazem ${ }^{21}$. Należy nadmienić, iż wspomniana sytuacja prowadzi do silnej konkurencji między użytkownikami serwisów randkowych, gdyż żaden z nich nie chce pozostać niezauważonym.

W tym miejscu warto nieco bliżej przyjrzeć się zjawisku konkurencji w odniesieniu do ludzkiej natury. Otóż jedna z interpretacji konsumpcjonizmu zakłada, że jest on napędzany właśnie przez naturę człowieka. W tym wypadku konsumpcjonizm nie jest narzuconym sposobem funkcjonowania, lecz oparty jest na nieustannej chęci rywalizacji między konsumentami. Thorstein Veblen wprost zaznacza, iż system nie inicjuje określonych zachowań, lecz jedynie dostarcza konsumentom narzędzi. Veblen, podobnie z resztą jak Bourdieu, odnosi przytoczoną teorię do klas społecznych: uczestnicy danej klasy społecznej manifestują swój status społeczny, by jak najbardziej zbliżyć się do klasy wyższej. Co jednak, gdy nie odniesiemy tego do społeczeństwa klasowego? Otóż, uczestnicy społeczeństw ponowoczesnych również będą manifestować swoją społeczną siłę, jednak po to, by podkreślić identyfikację z wybranym stylem życia ${ }^{22}$.

Zastanawiać może to, czy niezwykła popularność serwisów randkowych wynika $\mathrm{z}$ ich silnego oddziaływania na ich użytkowników, czy też to sami konsumenci, w swej chęci rywalizacji, sięgają po tego rodzaju narzędzia. W takiej sytuacji wirtualne randki niewątpliwie umożliwiałyby im walkę o status społeczny w danym towarzystwie (wyrażony chociażby poprzez zainteresowanie ich profilem czy osobą). Przede wszystkim jednak wartością nadrzędną byłoby nabycie towaru, w tym wypadku człowieka.

Eva Illouz przytacza pojęcie gospodarki obfitości, która znamienna jest dla serwisów randkowych. Internauci funkcjonując na swego rodzaju rynku, muszą dokonywać precyzyjnego rachunku kosztów i korzyści ${ }^{23}$. W dobie kapitalizmu czas stał się niezwykle cennym dobrem. Każdy z nas chce jak najszybciej i jak najefektywniej zaspokoić swoje potrzeby. Podobnie rzecz się ma z wirtualnymi randkami. Użytkownicy przeglądają setki profili i zdjęć współuczestników, by wybrać najbardziej interesujący i najlepiej rokujący. W końcu należy zminimalizować ryzyko popełnienia błędu, a tym samym zmarnowania czasu na nieudaną randkę offline. Proces poszukiwania partnera zrównany został w ten sposób z transakcją ekonomiczną. Własne ja utożsamione zostało z produktem, który rywalizuje z wieloma innymi produktami na rynku. Wszystko pod egidą prawa popytu i podaży ${ }^{24}$.

21 E. Illouz, op. cit., s. 120-121.

22 Ł. Iwasiński, op. cit., s. 57-58.

23 E. Illouz, op. cit., s. 124.

24 Ibidem, s. 128. 
Twórcy serwisów randkowych prześcigają się w możliwościach oferowanych konsumentom. Nie można pominąć faktu, iż spora popularność danej witryny internetowej związana jest nie tyko z częstotliwością jej odwiedzin, ale przede wszystkim $\mathrm{z}$ zyskiem. To także jedna z zasad rynku. Administratorzy randkowych stron internetowych za wszelką cenę starają się przyciągnąć uwagę odbiorców. Prezentowane są im usługi, które pomóc mają w znalezieniu miłości w jak najkrótszym czasie. Stąd obecność randkowych kwestionariuszy, w założeniu ułatwiających odnalezienie najbardziej interesującej osoby. Internauci w łatwy sposób mogą dokonać selekcji prezentowanych profili, określając preferowany wiek, płeć, kolor włosów, sylwetkę czy nawet stosunek do używek.

Wszystko to pobudzić ma internautów do aktywnego zawierania kontaktów w cyberprzestrzeni. Na pewno sprzyja temu fakt, iż w Internecie chętniej i odważniej niż w świecie realnym wyrażamy swoje myśli czy uczucia ${ }^{25}$. Tego typu zachowania wzmagane są poprzez poczucie anonimowości (użytkownicy nie muszą zamieszczać swoich zdjęć czy danych osobowych), ukrycie (użytkowników nikt nie widzi, pozostają oni oddzieleni szklanym ekranem monitora), a także neutralizację znaczenia pozycji społecznej (w Internecie wszyscy jesteśmy równi) ${ }^{26}$.

Wspomniane zjawisko zostało nazwane efektem rozhamowania sieciowego. Przejawia się ono w zdecydowanej swobodzie wygłaszanych opinii czy prezentowanych treści. Wyróżnić można rozhamowanie toksyczne (toxic disinhibition), które objawia się zachowaniami ocenianymi negatywnie (między innymi zachowania agresywne, nazbyt impulsywne czy też wulgarne). Nie można jednak pominąć także zachowań sprzyjających wyrażaniu własnych emocji, obaw czy myśli. W takim wypadku mowa o rozhamowaniu łagodnym (benign disinhibition) ${ }^{27}$.

Omówiona swoboda wyrażania swoich przemyśleń i oczekiwań w sieci zdecydowanie ułatwiać może nawiązywanie kontaktów online. Wystarczy jedno kliknięcie, by krótkim komunikatem rozpocząć konwersację z wybraną osobą. Oczywiście negatywna forma może ujawniać się w postaci nadmiernego zaufania wobec obcej osoby. Nie znaczy to jednak, że użytkownicy serwisów randkowych rezygnują z poznawania siebie wzajemnie w sieci. Świadczy o tym chociażby fakt, że czaty internetowe cieszą się sporą popularnością, a flirt jest ich nieodzowną częścią ${ }^{28}$.

Zwracając uwagę na flirt, nie sposób nie wspomnieć o miłości. Na tej płaszczyźnie życia serwisy randkowe również pozostawiły pewien ślad. Nawiązać można chociażby do miłości romantycznej, która to podkreśla niezwykłą istotność udziału dwóch ciał - fizycznych, namacalnych. W tym wypadku seksualne pożądanie opiera się na cielesności. Natomiast uczucie miłości romantycznej jest tak silne, iż wręcz zaburza

25 E. Aboujaoude, op. cit., s. 37.

26 J. Suler, The online disinhibition effect, „CyberPsychology \& Behavior” 7, 2004, nr 3, s. 321-325.

27 Ibidem.

28 N. Doering, Studying Online-Love and Cyber-Romance, [w:] Online Social Sciences, red. B. Batinic, U.D. Reips, M. Bosnjak, Seattle 2002, s. 5. 
dotychczasowy ład życia osoby zakochanej. Gwałtowne uczucia przepełniają umysł człowieka, by całą jego uwagę skupić na obiekcie westchnieńn ${ }^{29}$.

Zdecydowanie odmienną naturę przybierają relacje miłosne online. W tym wypadku prym wiedzie racjonalny i przemyślany wybór, a nie spontaniczne, gwałtowne uczucie. W odróżnieniu od realnej relacji miłosnej, to tekst pisany odgrywa znaczącą rolę, a nie ciało ${ }^{30}$. Internauci nie mają możliwości bezpośredniej rozmowy z sobą czy spojrzenia sobie w oczy. Ten etap wzajemnego poznania następuje już po dokonaniu wyboru i ewentualnie przeniesieniu relacji ze świata wirtualnego do realnego. To wtedy następuje weryfikacja treści czy materiałów zamieszczonych uprzednio w sieci.

Ta łatwość zawierania relacji internetowych, a przede wszystkim wielość dostępnych możliwości daleka jest od idei niepowtarzalności, czy też wyjątkowości drugiej osoby. Illouz wprost przyrównuje wirtualne relacje randkowe do masowej konsumpcji, która oparta jest na nieustannych możliwościach, a także na przemyślanych wyborach. Decyzje te jak najtrafniej mają spełnić oczekiwania konsumentów ${ }^{31}$. W tym wypadku sposoby zawierania relacji w przestrzeni serwisów randkowych przywodzą na myśl zakupy w sklepie. Konsumenci przeglądają dostępną „ofertę” i z setek "produktów” wybierają te, które wydają im się najbardziej atrakcyjne. W tego typu przestrzeniach nie ma czasu na uważne poznanie osobowości drugiej osoby. Na pewno nie na etapie początkowego kontaktu. Rolę pierwszego wrażenia odgrywa tekst (stosowane opisy, które często są niezwykle barwne i kreatywne), a także zdjęcia (niejednokrotnie modyfikowane poprzez wykorzystanie rozmaitych programów graficznych). Należy jednak mieć na uwadze fakt, iż konsumpcjonizm niewątpliwie daje konsumentom pewną władzę, ale jednocześnie wzmaga w nich poczucie frustracji, krępuje ich. Ludzie niezwykle mocno i szybko „wchłaniani” są do świata konsumpcjonizmu, lecz równie szybko mogą zostać z niego wykluczeni ${ }^{32}$.

W czasach powszechnej obecności nowych technologii mechanizmy działania znamienne dla konsumpcjonizmu niewątpliwie przedostały się także to sfery życia intymnego współczesnego człowieka. Relacje typowe dla serwisów randkowych upodabniają się do transakcji ekonomicznych zachodzących na wolnym rynku. Tego typu przemiany relacji międzyludzkich znamienne są dla społeczeństw kapitalistycznych, które oparte są na współzawodnictwie, a także na powszechnie obowiązującej zasadzie pomnażania dóbr. Powszechnym priorytetem dla mas staje się zaspokojenie potrzeb konsumenckich w jak najkrótszym czasie przy jednoczesnej minimalizacji nakładów pracy czy środków finansowych. Wszystko to wzmaga proces utowarowienia człowieka, który odbywa się naszych oczach.

29 Zob. M. Janion, Goraczka romantyczna, Gdańsk 2007.

30 E. Illouz, op. cit., s. 130-131.

31 Ibidem.

32 Zob. T. Edwards, Contradictions of Consumption: Concepts, Practices and Politics in Consumer Society, Buckingham 2000. 


\section{Online dating or flirt in the embrace of consumerism}

\section{Summary}

The article is about interpersonal relations established by dating sites users. The analysis is about the rules of using these types of websites, as well as the rules of developing virtual relations. It is mainly an attempt to decide whether consumerism is already present in such intimate spheres of human life as feelings, intimate relations or sexual life. In the era of capitalism, each of the spheres of modern human life has been changed. It is noticeable in the most private, intimate areas. The question is whether interpersonal relationships on dating websites are based on emotions, feelings or the transactional principle of multiplying goods. There is also a significant paradox of dating sites - on the one hand internet users are people who are looking for love, emotions, on the other, they are consumers. 